\title{
Epidemiology and molecular characterization of re-emerged virulent strains of Peste des Petits Ruminants virus among sheep in Kassala State, Eastern Sudan
}

\author{
Fatima A. Saeed ${ }^{1 *}$, Mohammed M.Gumaa', Sana A.Abdelaziz², Khalid A. Enan ${ }^{3}$, Selma K. Ahmed ${ }^{4}$ and
} Mohammed O. Hussien ${ }^{3}$

\begin{abstract}
Background: Peste des Petits Ruminants (PPR) is a severe contagious viral disease, which mainly affects small ruminants. PPR is caused by a Morbillivirus that belongs to the family Paramyxoviridae. In this study 12 suspected PPR outbreaks among sheep and goats were investigated in four localities in Kassala State, Eastern Sudan, during 2015-2017. The causative agent was confirmed by a Sandwich Enzyme-Linked Immunosorbent Assay (sELISA), and a Reverse Transcription Polymerase Chain Reaction (RT-PCR) targeting a partial sequence of nucleocapsid protein gene ( $\mathrm{N}$ - gene) and a partial sequence of fusion protein gene ( $\mathrm{F}$-gene). Sequencing and phylogenetic analysis were carried out on six N- gene based RT-PCR products selected from two outbreaks occurred on border and inner localities of Kassala State to determine the circulating lineages of PPRV strains. Identity percentages were determined between isolates in this study and previous Sudanese, and other (African and Asian) isolates which clustered along with them.

Results: Out of 30 samples, 22 (73.3\%) were positive using sandwich ELISA. From $22 \mathrm{~s}$ ELISA positive samples, 17 (77.3\%) were positive by Ngene based RT-PCR and only 7(43.8\%) out of 16 positive samples by N gene based RT-PCR were positive using Fgene based RT-PCR. The sequencing and phylogenetic analysis confirmed involvement of the lineage IV of PPRV in outbreaks among small ruminants in Kassala State and high identity percentage between our isolates and previous Sudanese and other (African and Asian) isolates.
\end{abstract}

Conclusions: The present study demonstrates that genetic relationship between PPRV strains circulating in sheep in Kassala State, Eastern Sudan, and PPRV strains characterized as lineage IV in neighboring African countries such as Eretria,Ethiopia, Egypt, and other Asian countries

Keywords: Epidemiology, Molecular characterization, PPRV, Sheep, Kassala, Sudan

*Correspondence: fatimasaeed206@gmail.com

${ }^{1}$ Kassala Veterinary Research Laboratory (KVRL), Central Veterinary

Research Laboratories (CVRL), Animal Resources Research Corporation (ARRC), Al Amarat, P.O. Box 237P.O. Box 8067, Khartoum, Sudan

Full list of author information is available at the end of the article

\section{Background}

Peste des Petits Ruminants (PPR) is a severe contagious viral disease which mainly affects small ruminants [1]. There are several reports of PPR occurring in other wild species, particularly in captive wild ungulates [2]. The disease caused by a virus belongs to the genus Morbillivirus of the family Paramyxoviridae [3] which grouped along with the Rinderpest virus in cattle, Measles virus original author(s) and the source, provide a link to the Creative Commons licence, and indicate if changes were made. The images or other third party material in this article are included in the article's Creative Commons licence, unless indicated otherwise in a credit line to the material. If material is not included in the article's Creative Commons licence and your intended use is not permitted by statutory regulation or exceeds the permitted use, you will need to obtain permission directly from the copyright holder. To view a copy of this licence, visit http://creativecommons.org/licenses/by/4.0/. The Creative Commons Public Domain Dedication waiver (http://creativeco mmons.org/publicdomain/zero/1.0/) applies to the data made available in this article, unless otherwise stated in a credit line to the data. 
in human, and Canine distemper virus in pets and wild animals species belonging to Canidae, Mustelidae, Procynonidae, Ailuridae, Elephantidae, and large Felidae [4]. PPR is characterized by depression, fever, discharges from eyes and nose, mouth sores, disturbed breathing, cough, diarrhea, and death [5]. PPRV has a single serotype which has been grouped into four distinct lineages were I, II, III, and IV based on sequence comparison of partial sequences of Fgene [6], Ngene [7], or Hgene [8]. All four lineages have been detected in Africa [9]. In Sudan, the first outbreaks of PPR were originally diagnosed as Rinderpest in 1971 and later confirmed to be PPR $[10,11]$, and then outbreaks continued to be reported all over Sudan. The annual vaccination program against PPR in Sudan using an attenuated vaccine (Strain $75 / 1$ ) has been established in 2002. Since then, a plan to control PPRV was launched, but organized vaccination campaigns were not well performed [12,13].

Kassala State is located in Eastern Sudan and shares porous international boundaries with Eritrea, Ethiopia, and other Sudanese States (Fig. 1). The virus was isolated from infected camels in a severe outbreak in Kassala State during August-October 2004 [14]. In last years, PPR had become endemic, and outbreaks were occurred throughout year involving different species, but virulent strains of the virus had been emerged from time to time causes a huge loss. Also PPR was investigated in four Sudanese states including Northern State, River Nile
State, Khartoum State, and Gezira State during 20162017 found that the prevalence was higher than previously documented [15]. Antibodies against PPRV were detected in cattle imported from Sudan to Egypt [16]. Prevalence and presence of PPR viral antigen were investigated in pneumonic lungs of apparently healthy camels at Tambul slaughter house, Gezira State, Central Sudan, demonstrating the exposure and probable sub-clinical infection in camels [17].

The present study reported a confirmed molecular characterization of the virulent virus strain among sheep in Kassala State, and its comparison with available sequences from GenBank database provides valuable information about epidemiology of PPR in Sudan.

\section{Methods}

\section{Outbreaks areas}

Kassala State is a border state and major area of animals' exportation. The state is divided into eleven localities. In this study, we have investigated the disease outbreaks in four localities which are rural Kassala, rural West Kassala, rural New Halfa, and Kassala (Fig. 1). The selected localities had records of suspected PPR outbreaks in which some of them are more severe in a period between October, 2015 and February, 2017. In 2015, there was an outbreak in rural new Halfa locality with clinical signs of fever, diarrhea, and abortion. In 2016, outbreaks were located in rural Kassala and rural West

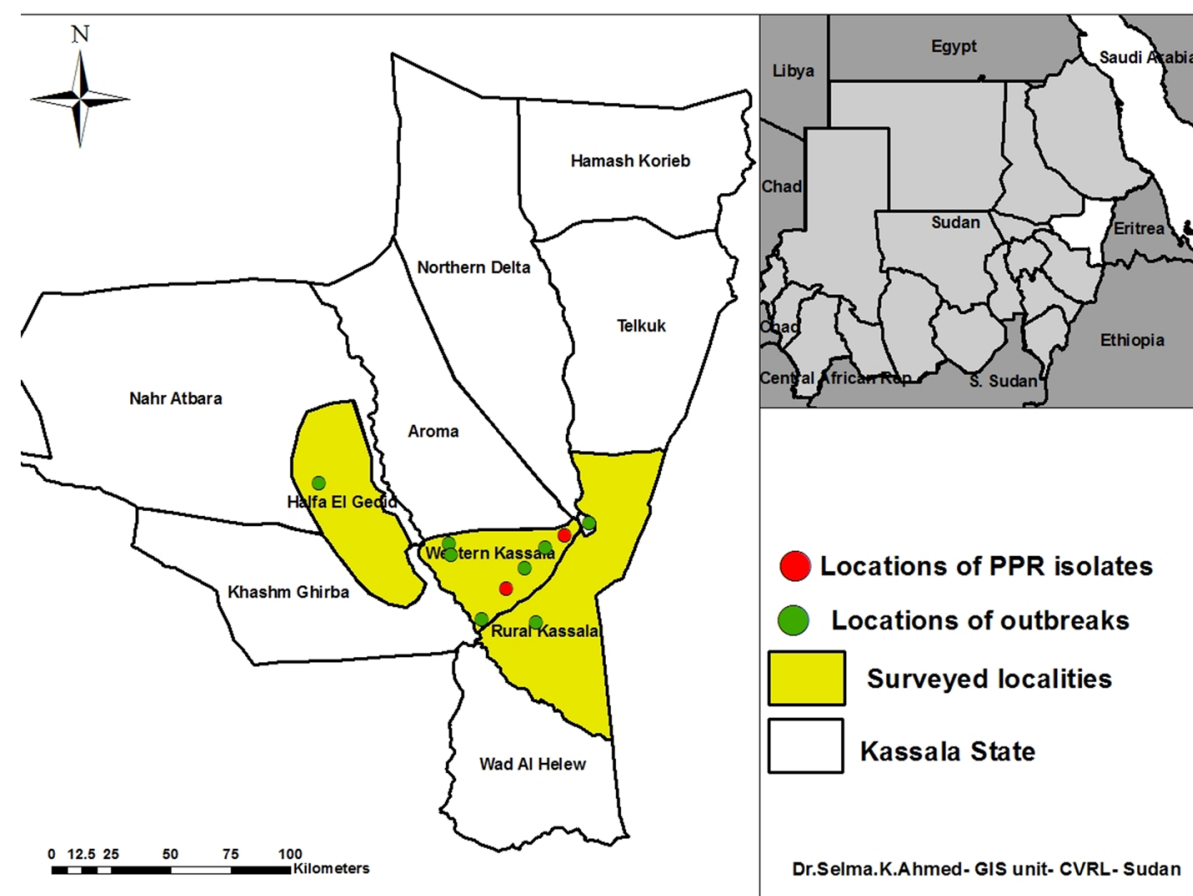

Fig. 1 Kassala State map showed surveyed localities (yellow color), locations of outbreaks (green circle) and location of PPR isolates (red circle) 
Kassala. The main signs were fever, diarrhea, lacrimation and oral erosions. Severe suspected PPR outbreaks among sheep flocks were occurred in February, 2017 in different villages of Kassala State with similar signs. Two of these villages (Noora and Kalhot) were visited after a few hours of onset of the disease symptoms. Noora village was located in rural West Kassala Locality representing the inner site of Kassala State whereas Kalhot village in rural Kassala Locality representing the border site of Kassala State. In these two outbreaks, the animals aged of 6-7 months from Garaj and Gash breeds were affected. Clinical signs are demonstrated in Table 1.
Detailed information about outbreaks from 2015-2017 is presented in Table 1.

\section{Outbreaks data and sample collection}

A total of 30 representative samples of 12 outbreaks were collected from sheep and goats with typical clinical signs of PPR in the febrile stage. Nasal, oral, ocular, and rectal swabs were collected using sterile swabs and preserved in transport media until analyzed. Blood in EDTA and fecal samples were also collected. Tissue samples including lymph nodes, lungs, intestines, spleens, and livers were aseptically collected from necropsied sheep. All samples

Table 1 Data of 12 suspected PPR outbreaks investigated in Kassala State

\begin{tabular}{|c|c|c|c|c|c|c|c|}
\hline Locality and Area & GPS data & flock size & infected animals & dead animals & Clinical signs & $\begin{array}{l}\text { collected } \\
\text { samples }\end{array}$ & Type of samples \\
\hline $\begin{array}{l}\text { Rural New Halfa } \\
\text { (faras village } \\
6 / 10 / 2015 \text { ) }\end{array}$ & $\begin{array}{l}N: 15.2578^{\circ} \\
E: 35.40416^{\circ}\end{array}$ & 150 goats & 11 & 3 & $\begin{array}{l}\text { Fever, abortion, } \\
\text { diarrhea, oral ero- } \\
\text { sions, }\end{array}$ & 2 & (O.S,R.S) \\
\hline $\begin{array}{l}\text { Rural Kassala } \\
\text { (Jabal eilak village } \\
\text { 1/9/2016) }\end{array}$ & $\begin{array}{l}N: 15.108060^{\circ} \\
E: 36.269701^{\circ}\end{array}$ & 40 sheep & 7 & 1 & $\begin{array}{l}\text { fever, diarrhea, } \\
\text { lacrimation, oral } \\
\text { erosions, nasal } \\
\text { discharge }\end{array}$ & 1 & $(N . S, R . S)$ \\
\hline $\begin{array}{l}\text { Rural West Kas- } \\
\text { sala (Kuliel area } \\
12 / 10 / 2016)\end{array}$ & $\begin{array}{l}E: 36.22225^{\circ} \\
N: 15.50405^{\circ}\end{array}$ & 200 sheep & 23 & 3 & $\begin{array}{l}\text { Fever, diarrhea, } \\
\text { oral erosions, } \\
\text { nasal discharge }\end{array}$ & 3 & (N.S,W.B) \\
\hline $\begin{array}{l}\text { Kuliel area } \\
12 / 10 / 2016\end{array}$ & $\begin{array}{l}E: 36.22225^{\circ} \\
N: 15.50405^{\circ}\end{array}$ & 230 sheep & 8 & 20 & $\begin{array}{l}\text { Fever, Diarrhea, } \\
\text { nasal discharge, } \\
\text { cough }\end{array}$ & 2 & (R.S,W.B) \\
\hline $\begin{array}{l}\text { Rural Kassala } \\
\text { (Fatou village } \\
12 / 2 / 2017 \text { ) }\end{array}$ & $\begin{array}{l}N: 15.374091^{\circ} \\
E: 36.381524^{\circ}\end{array}$ & 120 sheep & 14 & 4 & $\begin{array}{l}\text { Nasal discharge, } \\
\text { grinting, diarrhea, } \\
\text { oral erosion }\end{array}$ & 2 & (N.S,O.S,R.S) \\
\hline $\begin{array}{l}\text { Rural West Kassala } \\
\text { (Kitralawaida area } \\
\text { 10/11/2016) }\end{array}$ & $\begin{array}{l}E: 36.18436^{\circ} \\
N: 15.47355^{\circ}\end{array}$ & 380 sheep & 37 & 6 & $\begin{array}{l}\text { Fever, nasal dis- } \\
\text { charge, lacrima- } \\
\text { tion, salivation,oral } \\
\text { erosion, diarrhea }\end{array}$ & 8 & $\begin{array}{l}\text { (Oc.S,N.S,O.S,R.S) } \\
\text { and L.N }\end{array}$ \\
\hline $\begin{array}{l}\text { Rural West Kassala } \\
\text { (Aledidat area } \\
\text { 7/12/2016) }\end{array}$ & $\begin{array}{l}N: 15.55470^{\circ} \\
E: 35.94391^{\circ}\end{array}$ & 300 sheep & 20 & 4 & $\begin{array}{l}\text { Fever, abortion, } \\
\text { nasal discharge, } \\
\text { grinting, oral ero- } \\
\text { sion, diarrhea }\end{array}$ & 2 & (O.S,N.S,R.S) and L.T \\
\hline $\begin{array}{l}\text { Rural West Kassala } \\
\text { (Almarmadaib } \\
\text { area 2/2/2017) }\end{array}$ & $\begin{array}{l}N: 15.064989^{\circ} \\
E: 36.045371\end{array}$ & 500 sheep & 30 & 25 & $\begin{array}{l}\text { Fever, lacrimation, } \\
\text { Nasal discharge, } \\
\text { diarrhea }\end{array}$ & 5 & (W.B)(N.S,F.S) \\
\hline $\begin{array}{l}\text { Rural West Kassala } \\
\text { (Noora village } \\
\text { 19/2/2017) }\end{array}$ & $\begin{array}{l}N: 15.24129^{\circ} \\
E: 36.18719^{\circ}\end{array}$ & 500 sheep & 90 & 20 & $\begin{array}{l}\text { Fever, lacrimation, } \\
\text { Nasal discharge, } \\
\text { diarrhea, }\end{array}$ & 8 & (W.B,N.S,F.S) \\
\hline $\begin{array}{l}\text { Rural Kassala } \\
\text { (Gllosit vil- } \\
\text { lage22/2/2017) }\end{array}$ & $\begin{array}{l}N: 15.32819^{\circ} \\
E: 36.15894\end{array}$ & 76 sheep & 15 aborted & 0 & $\begin{array}{l}\text { Abortion, nasal } \\
\text { discharge, diar- } \\
\text { rhea }\end{array}$ & 5 & (W.B),N.S,R.S) \\
\hline $\begin{array}{l}\text { Rural Kassala } \\
\text { (Kalhot area } \\
22 / 2 / 2017 \text { ) }\end{array}$ & $\begin{array}{l}N: 15.26885^{\circ} \\
E: 36.16069\end{array}$ & 300 sheep & 8 & 2 & $\begin{array}{l}\text { Fever, nasal } \\
\text { discharge, oral } \\
\text { erosion, bloody } \\
\text { diarrhea }\end{array}$ & 3 & (W.B)(N.S,O.S,R.S) \\
\hline \multirow[t]{2}{*}{$\begin{array}{l}\text { Kassala (Elswagi } \\
\text { Alshamaliya area } \\
\text { 14/2/2017) }\end{array}$} & $\mathrm{E}: 36.355586^{\circ} \mathrm{N}: 15.470446^{\circ}$ & 80 sheep & 10 & 4 & $\begin{array}{l}\text { Sudden death, } \\
\text { fever, diarrhea, } \\
\text { nasal discharge }\end{array}$ & 2 & $(N . S, R . S)$ \\
\hline & & 2876 total & 9.5\% ( morbidity) & $3.2 \%$ (mortality) & & & \\
\hline
\end{tabular}


were placed on ice in the laboratory, and then kept at $-20{ }^{\circ} \mathrm{C}$ until examined. The data of suspected PPR outbreaks are demonstrated in Table 1.

\section{Sandwich ELISA}

Sandwich ELISA was performed using a commercially available PPR antigen capture ELISA kit (IDvet, rue Louis Pasteur-Grabels-France). Thirty samples (two goats and 28 sheep) from the 12 PPR suspected outbreaks were screened for the presence of PPRV antigen (nucleoprotein $(\mathrm{N})$ ). The test was performed according to the manufacturer's instructions. The reaction optical density was read at $450 \mathrm{~nm}$ using a microplate reader (LINEAR, Barcelona, Spain).

\section{RNA extraction}

Viral RNA was extracted from 22 samples using a commercial kit Qiamp Mini Kit (Qiagen, Germany) according to manufacturer's instructions.

\section{One step RT-PCR}

Twenty two samples which were positive by sELISA were tested for PPRV nucleic acid by one step RT-PCR amplification. The test was carried out using primer set directed to the conserved partial sequence of Ngene: (NP3) (Forward:5-TCTCGGAAATCGCCTCACAGA CTG-3) and (NP4)(Reverse:5-CCTCCTCCTGGTCCT CCAGAATCT-3) [18]. RT-PCR for Ngene was carried out at $45{ }^{\circ} \mathrm{C}$ for $15 \mathrm{~min}$ to activate transcriptase enzyme. Initial denaturation was performed at $95^{\circ} \mathrm{C}$ for $10 \mathrm{~min}$, followed by 35 cycles of $94{ }^{\circ} \mathrm{C}$ for $30 \mathrm{~s}, 60^{\circ} \mathrm{C}$ for $30 \mathrm{~s}$, and $72{ }^{\circ} \mathrm{C}$ for $1 \mathrm{~min}$, and a final extension step was performed at $72{ }^{\circ} \mathrm{C}$ for $10 \mathrm{~min}$. For Fgene RT-PCR, 16 samples were selected from Ngene based RT-PCR positive samples using a primer set directed to the Fgene of PPRV: f1b (Forward:5-AGTACAAAAGATTGCTGATCACAGT-3) and f2d (Reverse:5-GGGTCTCGAAGGCTAGGCCCG AATA-3) [19]. RT-PCR for Fgene was carried out at $45^{\circ} \mathrm{C}$ for 15 min to activate transcriptase enzyme, $95^{\circ} \mathrm{C}$ for 15 min as initial denaturation followed by 35 cycles of $95{ }^{\circ} \mathrm{C}$ for $1 \mathrm{~min}, 50^{\circ} \mathrm{C}$ for $1 \mathrm{~min}$, and $72{ }^{\circ} \mathrm{C}$ for $2 \mathrm{~min}$, and a final extension step was performed at $72{ }^{\circ} \mathrm{C}$ for 7 min using Biometra Thermocycler (Analytik Jena, Germany).

PCR products were subjected to electrophoresis in $2 \%$ agarose gel stained with ethidium bromide and visualized under ultraviolet (UV) light using a gel documentation system (Analytik Jena, Germany).

\section{Agreement between sELISA and N gene based RT-PCR}

The agreement between Sandwich ELISA and Ngene based RT-PCR applied in this study using 12 samples was calculated as concordance percentage (\%). Concordance percentage was calculated by division of the number of positive samples agreed by both sELISA and Ngene based RT-PCR by the total number of samples and multiplied by 100 .

\section{Sequencing}

Six Ngene based RT-PCR products ( three from border site (Kalhot village) and other three from e inner site (Noora village), were sent to Beijing Genomics Institute (BGI) (Beijing, China) for sequencing. The samples were sequenced using Sanger dideoxy Sequencing technology; both forward and reverse sequencing were performed on at least two independently generated PCR products. The sequencing results of six samples were subjected to Nucleotide-Nucleotide BLAST and Nucleotide-Protein BLAST tools in NCBI (www.ncbi.nlm. nih.gov) to confirm affiliation of the sequences to other PPRV isolates and translated sequences to PPRV nucleocapsid protein. Nucleotide sequences were submitted to the GenBank and get accession numbers: MG712792.1, MG712793.1, MG712794.1, MG712795.1, MG712796.1, and MG712797.1.

\section{Phylogenetic analysis}

The sequences were retrieved from the GenBank database and used for the construction of a phylogenetic tree using MEGA 6.0 software [20]. The evolutionary history was inferred using the neighbor-joining method [21]. To present the identity relation between Kassala-2017isolates and other isolates from sub cluster1 in constructed tree (Fig. 2), we compared their partial sequences of $\mathrm{N}$ gene together. The sequences identities were calculated using MegAlign software (DNASTAR Lasergene, Madison, Wisconsin USA).

\section{Results}

Among 30 samples tested by Sandwich ELISA, 22 (73.3\%) were positive. Twenty two samples that were initially tested positive by sELISA were tested by Ngene based RT-PCR, and 17/22 samples (77.3\%) were positive. Sixteen samples were selected from 17 samples tested positive by Ngene based RT-PCR, 7/16 (43.8\%) were positive using Fgene based RT-PCR (Table 2). The length of the PCR amplicons was $351 \mathrm{bp}$ for Ngene and 448 bp for Fgene. Twelve samples were used to compare sandwich ELISA and RT-PCR (Ngene), and out of them, 11 samples (animals) were positive for ELISA, nine for RT-PCR, and eight for both PCR and ELISA. This revealed an overall agreement (concordance) of $66.7 \%(8 / 12)$ between the two techniques (Table 3). 


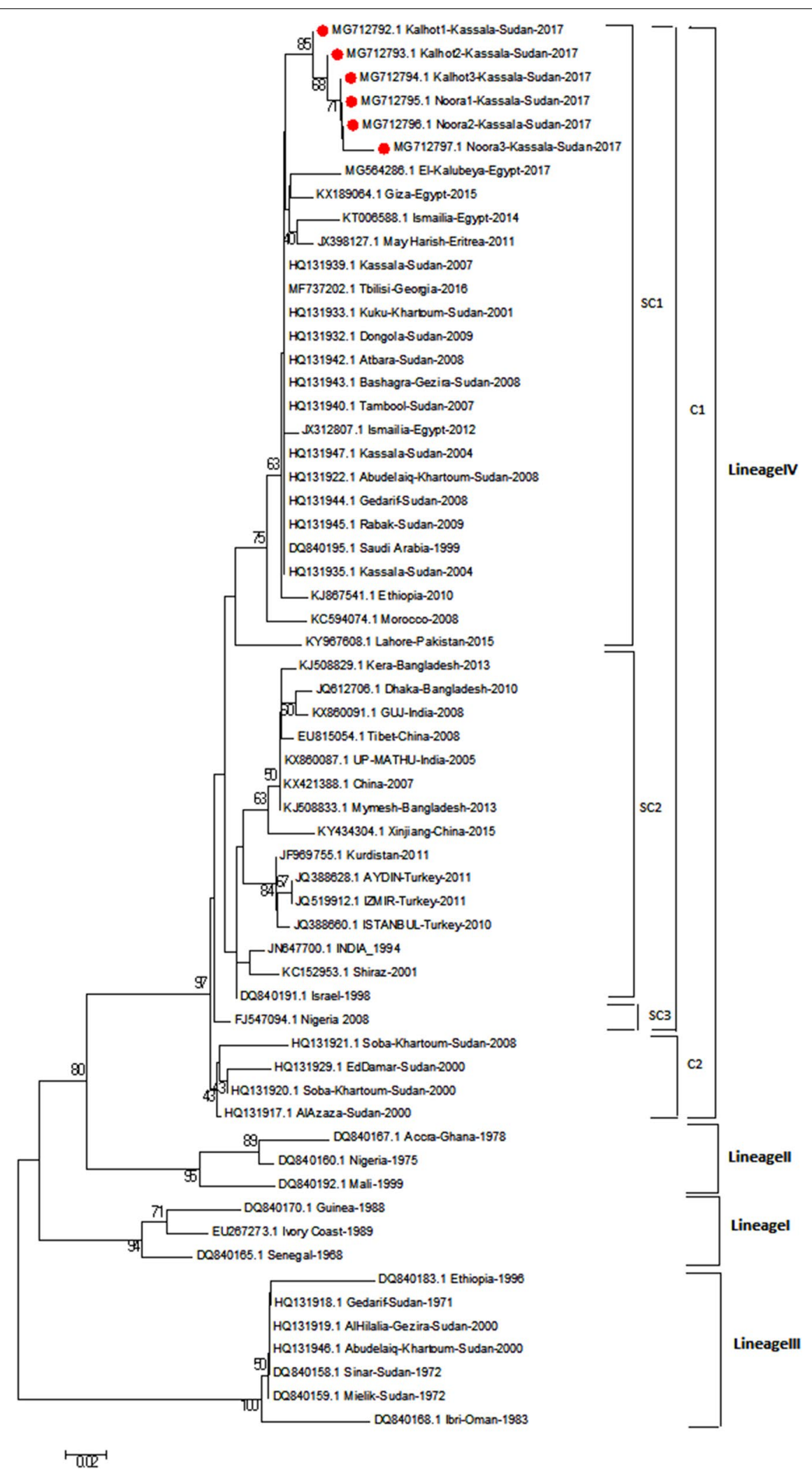

Fig. 2 Neighbor-joining tree using partial N gene sequences (351 nucleotide bases) showed the relationships between PPRV isolates from Kassala State outbreaks (indicated by red circle) and NCBI submissions. The tree constructed by MEGA 6.0 program. The tree topology was evaluated by 1000 bootstrap replicates. Onlyvalues $>70 \%$ are shown 
Table 2 Comparison of RT-PCR results for both genes that obtained from different samples in Kassala State, Eastern Sudan during 2015-2017

\begin{tabular}{|c|c|c|c|c|}
\hline \multirow[t]{2}{*}{ Sample Types } & \multicolumn{2}{|c|}{$\begin{array}{l}\text { RT-PCR (N gene) } \\
n=22\end{array}$} & \multicolumn{2}{|c|}{$\begin{array}{l}\text { RT-PCR (F gene) } \\
n=16\end{array}$} \\
\hline & + ve (\%) & -ve & + ve (\%) & -ve \\
\hline Swab & $9(81.8 \%)$ & 2 & $2(25 \%)$ & 6 \\
\hline Tissue & $3(100 \%)$ & 0 & $2(100 \%)$ & 0 \\
\hline Fecal sample & $1(100 \%)$ & 0 & $0(0 \%)$ & 1 \\
\hline Serum & $0(0 \%)$ & 1 & $0(0 \%)$ & 1 \\
\hline Whole blood & $4(100 \%)$ & 0 & $3(75 \%)$ & 1 \\
\hline Filter paper & 0 & 2 & N/A & N/A \\
\hline Total & 17 (77.27\%) & 5 & 7 (43.8\%) & 9 \\
\hline
\end{tabular}

Table 3 Cross-tabulation between sandwich ELISA and RT-PCR analysis results of 12 PPR clinical samples from Kassala State, Eastern Sudan during 2015 -2017

\begin{tabular}{lllll}
\hline Technique & RT-PCR (+) & RT-PCR (-) & Total & Concordance (\%) \\
\hline $\begin{array}{l}\text { Sandwich ELISA } \\
(+)\end{array}$ & 8 & 3 & 11 & $66.7 \%$ \\
Sandwich ELISA (-) & 1 & - & 1 & \\
Total & 9 & 3 & 12 & \\
\hline
\end{tabular}

The morbidity, mortality, and case fatality rates of the PPR outbreaks which are investigated in this study were 9.5\% (273/2876), 3.2\% (92/2876), and 33.7\% (92/273) repectively. Sequences' analysis of all six PPRV isolates in this study showed $98.3 \%-100 \%$ identity to each other.

Kassala-2017 isolates are clustered along with previous Kassala isolates, Egypt, Ethiopia, Eretria Georgia, Nigeria, Morocco, Saudi Arabia, Turkey, India, China, Bangladesh, Pakistan, Kurdistan, and Iran, while, other Sudanese isolates such as EdDamer, Alazaza and Soba are clustering together (Fig. 2). Nucleotide identity percentage between Kassala-2017 PPRV isolates and other PPRV isolates reported in the previous studies from Sudan was ranged between 94.9 and $96.6 \%$ (Fig. 3). Comparison of the nucleotide identity between Kassala-2017 PPRV isolates-and the other isolates in the subcluster1 of lineage IV indicated that the PPRV isolates from Kassala-2004 and 2007, Saudi Arabia-1999, and Georgia-2016 have an average nucleotide identity (97.5\%) whereas an average (96.2\%) of identity has been observed with Egypt isolates (2012, 2014, and 2015). In addition, Ethiopia-2010and Eretria-2011 PPRV isolates showed nucleotide identities were 96.6 and $96.2 \%$, respectively, while Morocco -2008 isolate showed identity $96.08 \%$ (Fig. 4).

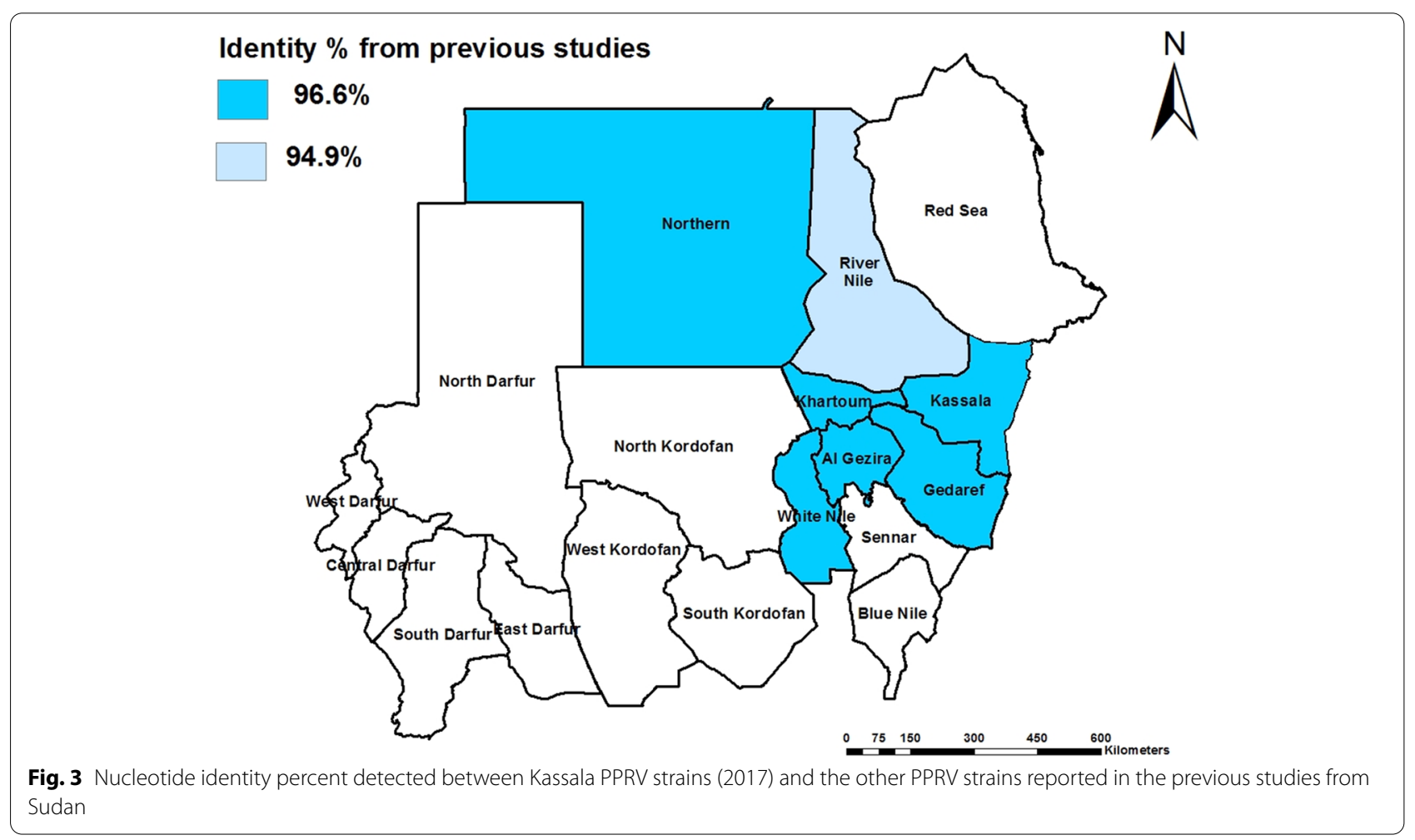




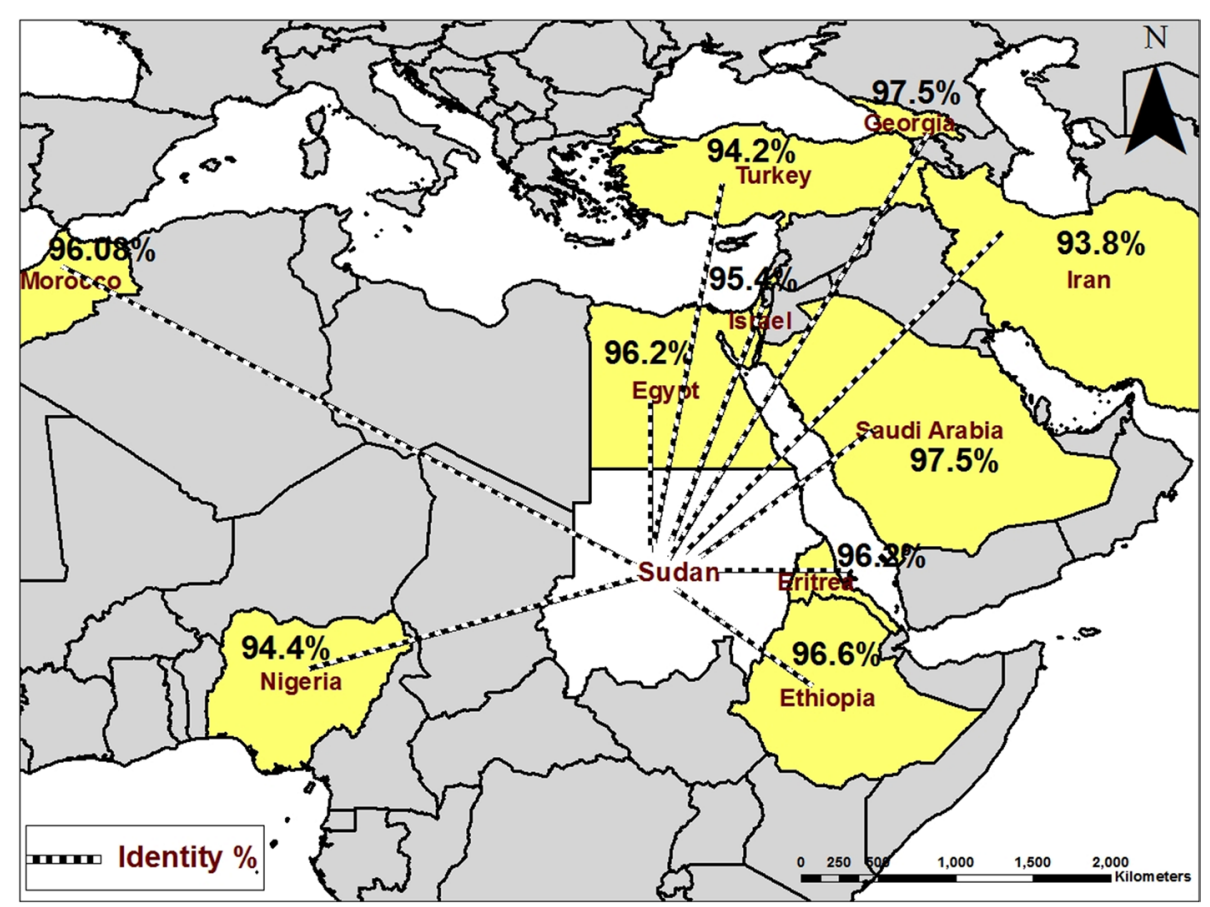

Fig. 4 Nucleotide identity percent detected between Kassala PPRV strains (2017) and the other PPRV strains reported worldwide

\section{Discussion}

This study describes 12 suspected PPR outbreaks among unvaccinated sheep and goats flocks in four localities in Kassala State, Eastern Sudan during 2015- 2017. In Sudan, many outbreaks of PPR were investigated during 1999-2001 in Khartoum, Gezira, White Nile, North Kurdofan, and River Nile States [22]. In the course of PPR outbreaks surveys, classic clinical signs and symptoms were noticed including fever, diarrhea (bloody), nasal discharge, lacrimation, cough, grinting, oral erosions, salivation, and abortion. Similar manifestations were reported in previous studies in experimentally infected goats by Coucay Hymann et al. [23] and naturally infected goats by Ullah et al. [24]. The morbidity, mortality, and case fatality rates of the PPR outbreaks in this study were 9.5, $3.2 \%$, and $33.7 \%$, respectively. This is in line with Diallo [25] who recorded the morbidity and mortality rates due to PPR ranging from 0 to $90 \%$ which are based on local husbandry practices, breed, age, and other risk factors. In PPR outbreak in Punjab area of Pakistan, the morbidity rate was $31.7 \%(19 / 60)$, mortality rate was $3.3 \%$ $(2 / 60)$, and case fatality rate was $10.5 \%$ [26]. In the present study, the presence of PPRV was proved by clinical signs, and antigen detection using Sandwich ELISA and RT-PCR techniques. The overall prevalence of PPRV herein reported was 73.3, 77.3, and 43.8\% using Sandwich ELISA, RT-PCRs for Ngene and Fgene respectively. This agrees with Mahajan et al. [27] who reported that
NP3 and NP4 primers for Ngene based RT-PCR showed the maximum sensitivity and specificity of PPRV detection in clinical samples compared Fgene primer based RT-PCR. This attributed to the first protein to be produced by PPRV. Ngene transcripts are produced before that of F-gene thus making $\mathrm{N}$ gene more suitable target for improving the sensitivity of RT-PCR for detection of PPRV from clinical samples [27]. Upon laboratory investigation, five samples were positive in Sandwich ELISA and were tested negative in Ngene based RT-PCR. This may be attributed to the presence of PCR inhibitors or viral RNA degradation (thermal degradation) in these samples.

Phylogenetic analysis of PPRV revealed that lineage I was limited to Western Africa and has not been reported since 1994 whereas, lineage II circulate in Western and central Africa. In addition, lineage III is restricted to East Africa and the Middle East [28]. Molecular typing conducted in this study indicated that Kassala-2017 isolates were clustered with lineage IV of PPRV. This is in accordance with Kwiatek et al. [29] who carried out molecular typing of enormous sampling of PPRV strains in Sudan during 2000-2009 and provided a strong evidence of the Asian lineage IV in Sudan. Similar results were reported by Khalafalla et al. [14] who characterized PPRV strains discovered among camels in Kassala State as lineage IV genotype. Moreover, the current study showed a genetic relationship 
between PPRV strains circulating in sheep in Kassala State, and PPRV strains characterized among camel in 2004 in the same state by Khalafalla et al. [14]. This finding is consistent with Kwiatek et al. [29] who reported that PPRV strains' lineage IV was defined further by two sub-cluster: one included camel and goats' isolates and some of sheep isolates, whereas the other contained only sheep isolates, and a finding suggests a genetic bias according to the host. The current study also indicated genetic relationship between PPRV strains circulating in sheep in Kassala State, Eastern Sudan, and PPRV strains in Eretria and Ethiopia. When comparing nucleotide sequences between Kassala2017 isolates and other isolates in the sub cluster1, it is found that there is high identity with these isolates that reach 100\% (Fig. 3 and Fig. 4). These close similarities between Kassala- 2017 isolates and Eretria and Ethiopia isolates ensure transboundary circulation of PPRV due to free movement of animals searching for pastures across porous borders between Kassala, Eritrea, and Ethiopia. In addition there are live animals trading of camels and small ruminants for meat consumption between Kassala and Egypt through (Shalatain) aperture (Northern border of Sudan) in Red Sea State that it may be the main factor of similarity of viruses circulating in Kassala and Egypt. In addition there is a major trading activity between Saudi Arabia and Kassala State through airlines or through Swakin port on Red Sea..

\section{Conclusions}

It could be concluded that PPRV belongs to the lineage IV genotype, which is responsible for outbreaks among sheep in Kassala State. In addition, the existence of the lineage IV in Kassala State may be due to spread of this lineage through transhumance and cross-border trade in small ruminants from neighboring countries where lineage IV is reported. Therefore, regular vaccination and regulation of animal movement between countries are important to establish crucial eradication program of PPR in Sudan.

\section{Abbreviations}

PPRV: Peste des Petits Ruminants virus; SELISA: Sandwich enzyme-linked immunosorbent assay; RT-PCR: Transcription polymerase chain reaction.

\section{Acknowledgements \\ The authors would like to thank Prof. Zhou Jizhang and Dr. Li Zhaocai. Also special thanks to Animal Resources Research Administration in Kassala State.}

\section{Authors' contributions}

FAS, KAE and MOH carried out the methodology. FAS and MMG performed sample collection, data analysis, results interpretation and drafted the manuscript. SAA contributed to the conception and design of the study and revised the manuscript. SKA contributed to maps designing. All authors read and approved the final manuscript.

\section{Funding}

This study was funded by Kassala Veterinary Research Laboratory (KVRL), Central Veterinary Research Laboratory (CVRL), Animal Resources Research Corporation (ARRC), Ministry of Animal Resources, Khartoum, Sudan.

\section{Availability of data and materials}

Data and materials are available upon request by the corresponding author.

\section{Declarations}

\section{Ethics approval and consent to participate}

Collection of blood from sheep and goats was performed by qualified veterinarians following proper physical restraint of animals to ensure both personnel and animal safety. Livestock owners were explained the study purposes and procedures and upon agreeing to participate, they provided a written consent prior to study procedures and blood collection from their animals. The study was approved by the ethics committee of the Central Veterinary Research Laboratory (CVRL), Animal Resources Research Corporation (ARRC).

\section{Consent for publication}

Not applicable.

\section{Competing interests}

The authors declare that they have no competing interests. The result of this study does not reflect the opinion of the funding sources. All authors have read and approved the final version of this manuscript.

\section{Author details}

${ }^{1}$ Kassala Veterinary Research Laboratory (KVRL), Central Veterinary Research Laboratories (CVRL), Animal Resources Research Corporation (ARRC), Al Amarat, P.O. Box 237P.O. Box 8067, Khartoum, Sudan. ${ }^{2}$ Department of Microbiology, Faculty of Veterinary Medicine, University of Khartoum, P.O. Box 32, Khartoum North, Sudan. ${ }^{3}$ Central Laboratory, Ministry of Higher Education and Scientific Research, P.O. Box 7099, Khartoum, Sudan. ${ }^{4}$ Central Veterinary Research Laboratory (CVRL), Animal Resources Research Corporation (ARRC), Al Amarat, P.O. Box 8067, Khartoum, Sudan.

Received: 7 April 2021 Accepted: 23 August 2021

Published online: 07 September 2021

\section{References}

1. Office of International Epizootics (OIE). Manual of Diagnostic Tests and Vaccines for Terrestrial Animals Chapter 2.7.11: Peste des petits ruminants. Available from: https://www.oie.int/international-standard-Setting/terre strialmanual/access-online, 2013

2. Kinne J, Kreutzer R, Kreutzer M, Wernery U, Wohlsein P. Peste des petits ruminants in Arabian wildlife. Epidemiology and infect. 2010;138(8):1211-4.

3. Murphy FA, Gibbs EP, Horsier MC, and Studdert, M J. Paramyxoviridae. In: Veterinary Virology. $3^{\text {rd }}$ ed. Academic press, pp 423 U.S.A; 1999.

4. Gibbs EP, Taylor WP, Lawman MJ. Classification of Peste des Petits Ruminants Virus as the Fourth Member of the Genus Morbillivirus Intervirology. 1979;11(5):268-74.

5. Roeder $P$ and Obi TU. Recognizing of Peste des petits ruminants, In: FAO Animal Health Manual (5). 28pp Publ. Food and Agriculture Organization of the United 'Nations, Rome; 1999.

6. Seth S, Shaila MS. The fusion protein of Peste des petits ruminants virus mediates biological fusion in the absence of hemagglutinin-neuraminidase protein. Virology. 2001;289(1):86-94.

7. Kerur N, Jhala MK, Joshi CG. Genetic characterization of Indian peste des petits ruminants virus (PPRV) by sequencing and phylogenetic analysis of fusion protein and nucleoprotein gene segments. Res Vet Sci. 2008:85(1):176-83.

8. Senthil Kumar K, Babu A, Sundarapandian G, Roy P, Thangavelu A, Siva Kumar K, Arumugam R, Chandran ND, Muniraju M, Mahapatra M, Banyard AC, Manohar BM, Parida S. Molecular characterization of lineage IV Peste des Petits ruminants virus using multi gene sequence data. Vet Microbiol. 2014;174:39-49. 
9. Banyard AC, Parida S, Batten C, Oura C, Kwiatek O, Libeau G. Global distribution of Peste des Petits Ruminants virus and prospects for improved diagnosis and control. J Gen Virol. 2010;91:2885-97.

10. Elhag $A B$. A natural outbreak of Rinderpest involving sheep, goats and cattle in Sudan. Bull Epizoot Dis Afr. 1973;21:421-8.

11. El Hag AB, Taylor WP. Isolation of Peste des Petits Ruminants virus from Sudan. Res Vet Sci. 1984;36:1-4.

12. Saeed IK, Ali YH, Khalafalla Al, Rahman-Mahasin EA. Current situation of Peste des petits ruminants (PPR) in the Sudan. Trop Anim Health Prod. 2010;42(1):89-93.

13. Ishag OM, Saeed IK, Ali YH. Peste des petits ruminants outbreaks in White Nile State. Sudan Onderstepoort Journal of Veterinary Research. 2015;82(1):1-4.

14. Khalafalla Al, Saeed IK, Ali YH, Abdurrahman MB, Kwiatek O, Libeau G, Obeida AA, Abbas Z. An outbreak of peste des petits ruminants (PPR) in camels in the Sudan. Acta Trop. 2010;116(2):161-5.

15. Osman NA, Ibrahim HMA, Osman AA, Alnour RM, GamalEldin OA. Sero-prevalence of Peste des Petits Ruminants virus antibodies in sheep and goats from the Sudan, 2016-2017. Virus disease. 2018;29(4):531-6. https://doi.org/10.1007/s13337-018-0496-7.

16. Hekal SHA, Al-Gaabary MH, El-Sayed MM, Sobhy HM, Fayed AAA. Seroprevalence of some Infectious transboundry diseases in cattle imported from Sudan to Egypt. J Adv Vet Anim Res. 2019;6(1):92-9. https://doi.org/ 10.5455/javar.2019.f318.

17. Abdalla NAS, Alhussain A.E. M, Mohammed S. I, Hakeem M, Ahmed I.H, Mohammed GE, Osman NA. Detection of peste des petits ruminants virus in pneumonic lungs from clinically apparently healthy camels slaughtered at Tambul slaughterhouse,

18. Central Sudan. Vet Med Sci. 2021. https://doi.org/10.1002/vms3.457. Couacy-Hymann E, Roger F, Hurard C, Guillou JP, Libeau G, and Diallo A. Rapid and sensitive detection of Peste des Petits Ruminants virus by a polymerase chain reaction assay. Journal of Virological Methods. 2002; 100(1-2): 17-25.

19. Ozkul A, Akca Y, Alkan F, Barrett T, Karaoglu T, Dagalp SB, Anderson J, Yesilbag K, Cokcaliskan C, Gencay A, Burgu I. Prevalence, distribution and host range of Peste des Petits Ruminants virus. Turkey Emerging Infectious Diseases. 2002;8(7):708-12.
20. Tamura K Glen S, Daniel P, Alan F and Sudhir K MEGA 6: Molecular Genetics Analysis Vertion 6.0. Molecular Biology Evolution. 2013:30(12):2725-2729,

21. Saitou N, Nei M. Molecular Biology. Evolution. 1987;4(4):406-25.

22. Saeed Kl, Khalfalla Al, El Hassan SM, El Amin MA. PPR in the Sudan: Investigation of recent outbreaks, Virus isolation and cell Culture Spectrum. J Anim Vet Adv. 2004;3(6):361-5.

23. Couacy-Hymann E, Bodjo SC, Danho T, Koffi MY, Libeau G, Diallo A. Early detection of viral excretion from experimentally infected goats with Peste des Petits Ruminants virus. Prev Vet Med. 2007;78(1):85-8.

24. Ullah RW, Zahur AB, Latif A, Dasti Jl, Irshad H, Afzal M, Rasheed T, Malik AR, and Qureshi Z. Detection of Peste des Petits Ruminants viral RNA in fecal samples of goats after an outbreak in Punjab Province of Pakistan: A longitudinal study. BioMed Research International. 2016; Article ID 1486824, 5 .

25. Diallo A. Control of peste des petits ruminants and poverty alleviation. J Vet Med Series B: Infectious Diseases and Veterinary Public Health. 2016;53(1):11-3.

26. Abubakar M, Manzoor S, Wensman JJ, Torsson E, Ali Q, Munir M. Molecular and epidemiological features of Peste des Petits ruminants outbreak during endemic situation. British Journal of Virology. 2016;3(4):123-9.

27. Mahajan S, Agrawal R, Kumar M, Mohan A, Pande N. Comparative evaluation of different $\mathrm{F}$ and $\mathrm{N}$ gene based reverse transcription polymerase chain reaction for molecular detection of Peste des Petits Ruminants virus from clinical samples. Vet Arhiv. 2016:84:485-92.

28. Libeau G, Diallo A, Parida S. Evolutionary genetics underlying the spread of peste des petits ruminants virus. Anim Front. 2014;4(1):14-20.

29. Kwiatek O, Ali YH, Saeed IK, Khalafalla Al, Mohamed OI, Abu Obeida A, Abdelrahman MB, Osman HM, Taha KM, Abbas Z, El Harrak M, Lhor Y, Diallo A, Lancelot R, Albina E, Libeau G. Asian lineage of peste des petits ruminants virus. Africa Emerg Infect Dis. 2011;17:1223-31.

\section{Publisher's Note}

Springer Nature remains neutral with regard to jurisdictional claims in published maps and institutional affiliations.
Ready to submit your research? Choose BMC and benefit from:

- fast, convenient online submission

- thorough peer review by experienced researchers in your field

- rapid publication on acceptance

- support for research data, including large and complex data types

- gold Open Access which fosters wider collaboration and increased citations

- maximum visibility for your research: over $100 \mathrm{M}$ website views per year

At BMC, research is always in progress.

Learn more biomedcentral.com/submissions 